\title{
TRANSACTIONS \\ OF THE \\ PHILADELPHIA ACADEMY OF SURGERY.
}

\author{
Statcd Mectiug held October I, tgo6.
}

The Viec-Presiclent, RomerT G. LE ConTE, M.D., in the Chair.

\section{LYMPHANGEIOMA OF THE CHEEK}

Dr. Francis T. Stewart reported the ease of an infant, who was seen by him with Dr. Robert Pitfield soon after birtl. The whole right side of the faee was oeeupied by a soft semiflnetuating mass whieh extended from the mid-line of the upper lip baek over the parotid, and from the orbit down over the lower jaw (Fig. 1), and whiel bulged into the month. The right eye was elosed, the nose displaced to the left, and the mouth distorted. A hollow needle passed into the elieek withdraw a small quantity of straw-eolored fluicl. The skin was exeeedingly thin and eontained a few dilated veins but was not adherent. It was thought advisable to postjone operation as long as possible in orcler to give the infaut a firmer hold on life. At the end of four months, however, the swelling had distinetly inereased in size and there was evidenee of pressure effeets on the upper jaw. Immediate operation was therefore advised. The skin was refleeted by an ineision similar to that employed by Weber for reseetion of the upper jaw, and the growtl, which had also extended backwards along the floor of the orbit for abont one-half inel, enueleated with but little loss of blood. There were apparently no musele fibres in the eheek and at the eompletion of operation nothing remained but bone and very thin skin. After reseeting the redundant portion of the flap, the mueons membrane ivas sutured to the jaw with eatgut and the entaneous ineision elosed with horsehair. Jnst as the operation was completed the baby eeased to breathe (ether had been employed) and artifieial respiration was 
needed for some minutes. Primary union was secured except at a point corresponding to the inner canthus, which healed by

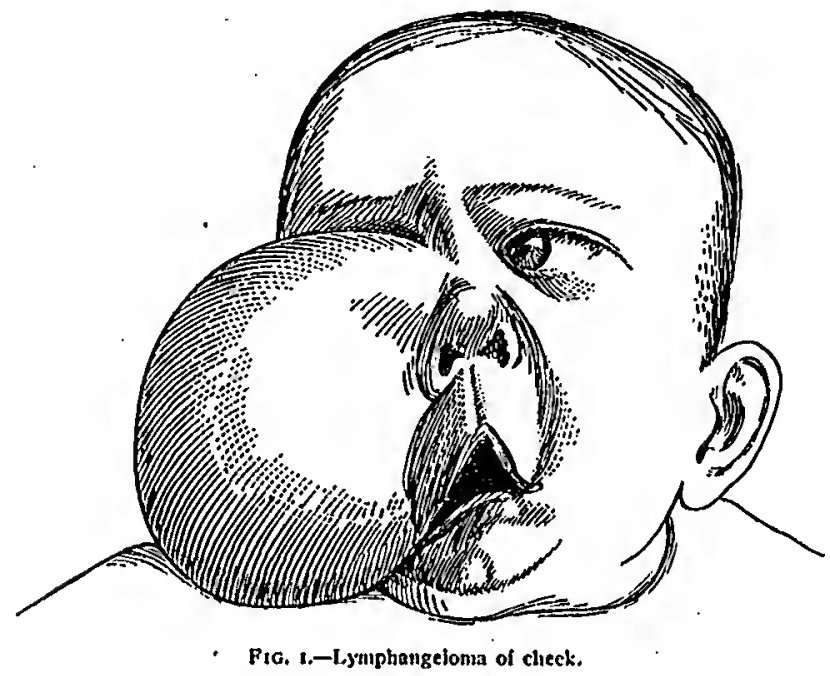

grantlation. The right face, of course, is sunken, the nose is still displaced to the left, and the lower lid and upper lip are slightly out of alignment.

\section{SARCOMA OF PUBES.}

Dr. Francis T. Stewart described the case of a woman aged 38 years, a multipara, who had never had any serious illness until the present time. The family history presents nothing relevant. About one year ago she fell against the corner of a table, striking the pubes. The blow was sharp enough to make a distinct impression on her memory, but did not incapacitate her and the soreness passed away in a short time. Four months ago pain appeared rather suddenly in the region of the injury and has since caused considerable discomfort, although it was never deemed serious enough to demand the services of a physician. Quite recently a swelling was noticed in the lower abdomen, and it was for such that the patient sought advice. There had been but little loss in weight, and the anæmia which was noted was said to have been present for many years. The tumor 
extended from the right anterior superior spine of the ilium to the left for $7 \frac{1}{2}$ inehes, and rose abont $2 \frac{1}{2}$ above the pubes, to the posterior surface of whieh it was firmly attaehed. The lateral extension on the right was moderately movable. The skin was at no plaee adherent. The growth was smooth, slightly lobulated, a little tender, and as hard as eartilage. The superficial veins were distencled but no other presure symptoms were in evidenee. The growtl eould be felt by vaginal examination but did not invade the uterus or appendages.

Operation was performed September 15, 1906, in the Pennsylvania Hospital. A long eurved ineision was made from the right anterior superior spine downwards and inwards aeross the

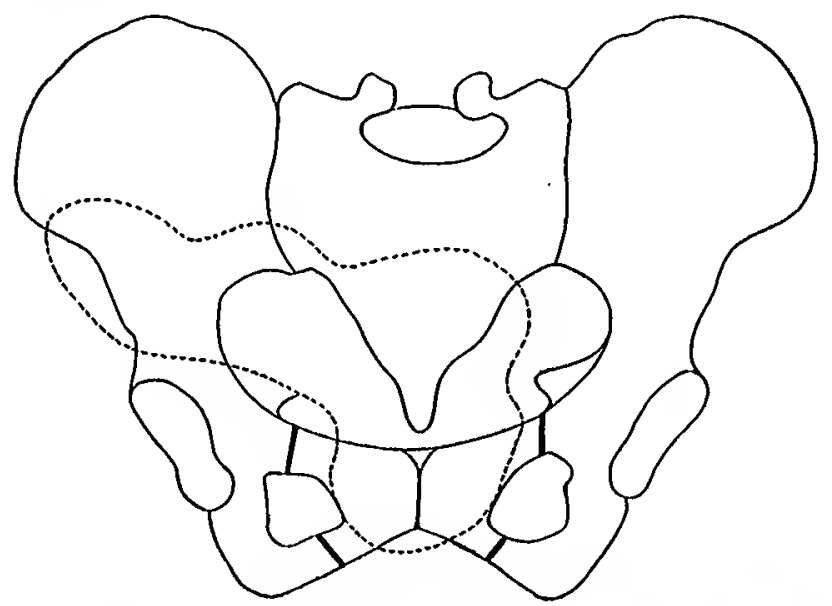

Fig. 2,-Sarcoma of pules. Dotted line slowing limits of tunor. Dark lines showing points al which bone was cut.

abdomen to the extreme limit of the growth on the left. As the abdominal muscles were invaded, they were severed above the growth, thus exposing the peritoneum which was peeled from the mass except at three points where it was so firmly adherent that it tore, necessitating the use of eatgut sutures. The bladder was not involved but the growth had displaeed the right external iliae vessels outwards and appropriated about two inches of the vein, which was therefore tied and severed above and below. Both round ligaments were eut and the remaining superfieial 
soft structures separated or divided. The lower margin of the wound was then refleeted downward, and both pubic bones separated from their fellows by the chisel, the amount of bone removed measuring four inches transversely (Fig. 2). The obturator vessels on the left were preserved, those on the right werc sacrificed. Beginning on the left, the bone was elevated after some diffieulty and foreibly turned to the right as the museular and ligamentous attaclinents were severcd. It was possible to suture a portion of the lateral muscles on the right to Poupart's ligament, but the recti had rctracted to the unbilicus and, as the operation had already consumed about two hours, no plastic work was attempted. The skin-wound was simply sutured exeept at the middle and the right end, where gatuze drains werc placed. Intravellons infusion was nccessary towards the elose of the operation but subsequently reaction progressed umaided. The following day the right leg was somcwhat bluish in color and was evidently larger than the left but there was no oedcula; there was, however, a sensation of "pins and needles" in tice foot and the wholc limb was noved with difficulty. On the second day the drains were removed but had to be replaced because of the large amount of lymph which was discharged. CEdema did not appcar until the third day and has never beell excessive. On the fifth day pus appeared in the wound but the infection has been comparatively benign and will probably not war the result. It should also be noted that there has never been any difficulty with the bladder or bowels, despite the abscnce of museles over the lower abdomen.

Examination of the specimen showed that the growth cvidently sprung from the periostcum eovering the posterior surface of the pubcs. Microscopic investigation revcaled a typieal spindle-celled sareoma.

\section{STAB WOUND OF THE INTERNAL MAMMARY ARTERY.}

DR. JoHN H. Jorson reportcd this case mainly beeause of the comparative rarity of the lcsion and because it is the only instance he has eneountered. The important vessels of the eliestwall that are liable to injury are the intercostals and the intcrnal mammary. Only 15 cases of wound of the intercostals were recorded during the Civil War. In 1892 Sehwartz colleeted 52 eases of injury of the internal mammary artcry which had been 
reported during the past century. Among these were seven in which the artery had been opened during operation and these he excluded, leaving 45 cases of wounds proper. Surgically the internal mammary are more important than are the intercostal arteries.

Dr. Jopson's case was that of a man of 50 years who was brought to the hospital at Io A.M. with a history of having been stabbed a short time before. The man's clothing was saturated with blood and he was in a state of collapse, being practically exsanguinated. He was also under the influence of liquor. The wound was an inch in length, two and one-half inches to the right of the sternum in the second interspace, passing obliquely upward and inward; it was not bleeding. The resident plyysician applied a dressing and administered stimulants. At I P.M. Dr. Jopson saw the man. The wound was not bleeding, but thongh the man had reacted to stimulation the pulse was still of poor quality. At 4 P.M. the wound was examined and was not bleeding, but in a few minutes $\mathrm{Dr}$. Jopson was ealled from the operating-room and found that severe hamorrhage had begin. Compression was applied and the patient was at once prepared for operation. At this time he was not certain that the heart was not wounded. An anæsthetie was given and the wound enlarged. The internal manmary was found divided in the second interspaee and both ends were bleeding. Both were tied with eatgut sutures whieh included the surronuding muscle. Salt solution was infused, an iodoform gauze drain inserted into the pleura, and a dressing applied and the patient sent to the ward. The pulse reacted but soon went down and the man died that night. Autopsy by the coroner's physician showed atheromatous vessels. The pleura was full of blood but there had been no leakage from the ligated vessel. No other organs were injured.

Dr. Jopson said that the subject of wounds of the internal mammary artery had been specially investigated by Schwartz in his Königsburg dissertation, in which he analyzes 45 cases, as previously mentioned. Of the 45 , nine died of aeute hremorrhage, which in four came from a wounded lung, heart or other neighboring structure, in 4 from the artery itself, and in I from an undetermined source. Of the 36 who survived the immediate effects, the wound becance infected in 24 , of whom 18 clied and six recovered. Of the 12 with uninfected wounds, 8 recovered and 4 died. 
There were 21 eases of secondary hemorrhage, 16 in the infeeted group, 5 in the uninfeeted group. In Dr. Jopson's ease the eonseeutive hæmorrhage was brought about by strain during vomiting. In the reported eases, sceondary liamorrlinge was dine in some to vomiting, in others to straining at stool, or other museular exertion. Selowartz coneluded that ligature of the vessel is not an infallible means of preventing secondary hamorrhage. He believes that immediate ligature is not neeessary, it being better to seal the wound primarily and raise the intrathoracie tension. The pleura is wounded in a large number of eases and this favors the continuation of hremorrlage. Dr. Jopson believes that primary ligature is advisable. He also believes it would be better if we were more radieal in our treatment of all penetrating wounds of the ehest. Often we are too eonservative in the presenee of hremorrhage, and even in the ease of penetrating wounds of the ehest in general. A year ago he reported a suceessful case of suture of the lung for hemorrhnge, and diseussed the question of inserting a drainage-tube and controlling bleeding by establishing a pneumothorax as recommended by Le Conte. It is better to resort to a ligature of the bleeding vessel if it ean be applied; if this eannot be done, then the establishment of a pneumothorax may be tried in hxmorrhage from the lung. In any ease, even if the bleeding has eeased, infeetion is apt to oceur. Two eases of ehest wound he has had to treat in the past twelve months as empyema beealse of the eonsequent infeetion.

Dr. Edivaro Martin, speaking on the general subjeet of penetrating wounds of the ehest, put on record a ense bearing on the question of hæemorrhage. A negro elimbing into a window was shot in the third interspace one-half inel to the right of the sternum. When seen later he exhibited the symptoms of hæmopnetımothorax and progressive bleeding. An osteoplastic flap was turned back, revealing a ent internal mammary artery whieh was not bleeding. The man was turned on his side and three pints of blood poured out of the pletra. $A$ bullet-wound of the lung, though not bleeding, was sutured and the lung sutured to the parietes. Though there was evidenee of use of the hung afterward, the man died in ten hours from progressive bleeding. Autopsy showed that the internal mammary had not bled but that hæmorrhage hacl oeeurred fron an intereostal artery which had been eut one and one-half inehes from its origin by the bullet 
which had broken a rib close to the vertebral articulation. Had the X-rays been in use at that time the man might possibly have been saved. The case is recorded as an instance of a wounded internal mammary artery not blecding and an intercostal bleeding which caused death.

Dr. Grorge G. Ross eited a case in which he is not able to say whether or not the internal mammary artery was wounded. The subject was an obese colored woman who was shot in the right side, the bullet going across into the left side also. The patient was in shock and there were indications of hæmorrhage. She reacted, however, and as there was no external liæmorrhage operation was not performed. Ten days later Dr. Ross evacuated two quarts of foul pus from the left pleura. As the woman recovered he docs not know what internal organ was injured.

Dr. Ronert G. LE. Conte said that he had carricd out experiments on the cadaver to determine the frequency of injury to intercostal vessels in wounds of the chest. His results appeared to demonstrate that the intercostal artery at the lower border of a rib would not be injured unless the rib showed marks of violence. The internal mammary artery is lialf an inch from the border of the sternum, and in ease of a wound in this locality there is always the probability of injury of that vessel, and exploration should be made. If the artery is wounded as low as the fourth or fifth interspace it is questionable if the hiemorrhage will be severe enough to cause death, while if the wound is in the second interspace the resulting hemorrhage will be fatal unless controlled. Should the vessel be injured below the third interspace-that is, below the origin of the triangularis sterni muscle-lıæmorrliage may be controlled by packing against the muscle. Dr. Le Conte las seen this done in onc case. Above this point the pleura alone is beneath the vessel, and packing cannot be employed, hence resection of a costal cartilage or cularging the wound sufficiently to expose the artery must be done. The greatest danger of lixmorrhage is of conrse from a vessel that has not been completely severed.

Dr. Le Conte's experience with hemorrhage from the lung is limited, but in his few cases of scvere hemorrhage he has simply made an opening in the pleura and allowed air to be drawn in. The rapidity of the formation of complete pnet1mothorax can be graded as desired. If alarming symptoms super- 
vene the opening ean be temporarily elosed, followed later by the insertion of a smaller tube. He has seen no instance of this expcdient failing to control hamorrhagc, and consequently has never had to seck a bleeding vessel in the lung. It is the ideal treatment, but where the patient fails to improve resection of one or more ribs becomes necessary, with a scarch for and dircet control of the blceding point.

Dr. Jorson, in closing, said that Schwartz's experiments on animals had shown the rapidity of blecling from the internal mammary. A small vessel cut a short distance from the large onc of which it is a branch will blced almost as profusely as will a similar opening in the trunk itsclf. When the internal mammary is cut in the sccond interspace it is practically equivalent to making an opening the size of that vesscl in the subclavian.

\section{SURGICAL TREATMENT OF PERFORATING ULCER OF THE STOMACH.}

Dr. Robert G. Le Conte read a paper with the above title (for which see page 907).

\section{PERITONITIS WITHOUT VISCERAL LESION.}

Dr. Edward Martin reported several cases of this condition (for which sec page 917).

Dr. Jorr $H$. Grnbon regards Dr. Le Conte's first two eases as teaching the lesson that gastric ulcer is probably much more common than we think. Surgeons do not get more cases because the diagnosis is not more frequently made. In the scrics reported by Dr. Le Conte were two cases which gave no symptoms and in three of his own seven there was no history to lead to suspicion of uleer. Since he reported four eases a few years ago he has met with three more as follows:

CASE I was in a man of 50 with the typical history and symptoms of a gastric uleer for a number of years. When seen by Dr. Gibbon he had been sick 36 hours and had all the evidence of general peritonitis. Operation revealed peritonitis and also a gastric uleer but without perforation. Drainage was established but the man died next morning. At autopsy the entire alimentary traet was removed but showed no lesion except the gastric uleer. There was a diffuse peritonitis and no adhesions to the ulcer. Dr. Gibbon believes it is possible to get infection of the peritoneum 
from a non-perforated gastrie uleer, just as this eondition arises from the appcndix, without maeroscopic perforation.

CASE II was a man, a typical alcololic, who had a leadpencil-sized perforation in the anterior wall of the stomach. The patient died five days later from delirium tremens.

CASE III was the onc referred to by Dr. Le Conte. There was the typical history of perforating ulccr, tlirec-fourtlis grain of morphin having afforded no relief from the pain. The perforation was in the anterior wall toward the lesser curvature. It was patched up by means of omentum and the paticnt recovcred.

Of the seven eascs seen by Dr. Gibbon threc recovered. In two, dcath was due to latcuess of operation, in onc to delirium tremens, and in one to faulty tcchnic. The last mentioned died on the twenty-fourth day from obstruction of the bowel and absccss of the pclvis. The inscrtion of a drain is the safest procedurc for the majority of surgeons. He always feels more sccure when a drain extcuds down to the point of perforation. The question of suprapubic drainage should be deeidcd by the length of time that has elapsed after perforation and by the quantity and claracter of the fluid in the peritoneal cavity. Dr. Gibbon las always uscel suprapubie drainagc. As to gastrocnterostony when onc is in cloubt as to whether the pylorus lias been closed in repairing the perforation, one point is to be remembered. Expcrience in elosing typhoid and gunshot perforations of the intestine when thic surgeon belicves the gut is almost elosed but finds later that the lumen is sufficicntly open, makcs one think that the pylorus will likewise stand a great deal of narrowing. Regarding sccondary gastro-enterostomy Dr. Gibbon did one 18 montlis after operation for perforation. Hc agrecs with $\mathrm{Dr}$. Lc Contc that it is a mistakc to do a gastro-cnterostomy when perforation is present. - It opens a new field for infection and is bad teclnic.

Regarding Dr. Martin's paper on pcritonitis witllout visccral lcsion, the surgcon not infrequently finds no causc to account for pcritoncal infcetion and feels that possibly he has overlooked a lesion. It is comforting to licar that postmortcu in the reported eascs revealed no discoverable souree of the peritonitis. Many such cascs arc probably due to the pncumtocoeeus.

Dr. Gibbon is partial to loeal anrestlesia, but this is not satisfactory for cxploring the abdomen, licnce ctliyl ehlorid is used 
for this purposc. Fonr thousand cases of ethyl chlorid anæesthesia are now on record at the Pennsylvania Hospital. This anæsthetic is very satisfactory, cspecially if it is preccded by a small dose of morphin. He did a colostomy by its aid and the man was talking to him whilc the dressings were being applied. It is the idcal agent for short operations.

Dr. William L. Rodanan is satisfied that the literaturc on the subject of gastric ulecr, in so far as perforation is concerned, has to be rewrittcu, as perforation is far more frequent than has hitherto been drcamed. During last May he spent a fortnight with Dr. Mayo, and dnring that time saw him operate on 12 cases of gastric and duodenal ulcer, and of these threc had previously perforated; in all threc the evidence was conclusive. Dr. Rodman has operated on threc cases of perforated gastric ulcer which were latent, and previous to perforation prescnted not the slightest sy'mptom suggestive of ulcer. In one instance one of the best medical men in the city had been in attendance and had not suspected the presence of ulcer.

As to the wisdom of drainage he agrees with Dr. Le Conte. It is not absolutely necessary in all cases but is very generally advisable. Suprapubic drainage is not neccssary in the majority of instances but the necessity for such drainage must depend upon whether or not there las been gross soiling of the peritonenm and whether the extravasated material has wandered far from the site of perforation. If perforation occurs shortly after a meal, then suprapubic drainage would be indicated; if when the stomach is empty, it usually will not be needed. It must be remembered also that in a large percentage of cases of perforation, as shown especially by Cripps and English, the stomach contents are sterilc, and far differcnt from the intestinal contents.

As to performing gastro-enterostomy after dcaling with a perforation, Dr. Rodman agrecs with Drs. Le Conte and Gibbon that it is wholly unnceessary unless there be stenosis of the pylorus. Dr. Gibbon raised the question as to whether it is better to excise the ulcer than to do gastro-enterostomy. Both are in most instances unwisc, but if the ulcer is accessible and the surrounding tissue not too necrotic, then excision is preferable to gastro-enterostomy. In regard to Dr. Martin's paper, he also has failed to find perforation in some cascs and yet peritonitis was present. However, there is no reason why we may not find 
peritonitis without macroscopie lesion of the viscera. Infection of intra-abdominal tumors may occur because of their prolonged contact with hollow viscera; and without apparent lesion uterine fibroids lave become infected through the intestine or the bladder. If then infection of tumors may occur in this way why should not peritonitis be caused in the same manner? Dr. Rodman agrees in the wisdom of using local anxsthesia, but it is unwise to attempt it in the ease of elikchen. He has several times performed laparotomy uncler local anesthesia, using a weak solution of cocaine. In one case he used only earbolic acid. There was no pain exeept when the parietal peritoneum was eut. The patient was dull and in a semi-stupor and perhaps not so appreciative of pain as the average ease.

Dr. Joun H. Jorson said that Dr. Martin mentioned finding the streptococcus in one of his eases of peritonitis without evident visceral lesion. In pediatric literature a constantly inereasing number of cases of pneumococeus infection of the peritoneum are being reported. Clinically these eases are diffieult to distinguish from those of streptococeus or other infection, and unless eultures are unade a pneunococeus infection could not be exeluded in the elass of eases under diseussion.

Dr. Francis 'T. Steivirt has operated on seven eases of perforated gastric uleer and in six he used drainage. Five recovered. In one lie elosed a perforation, did a gastro-enterostomy, and employed no drain; the patient recovered. He also omitted drainage in a case of typhoid perforation and the patient recovered. He eleans the peritoneum by irrigation with salt solution after thoroughly packing oft the surrounding structures. Dr. Stewart assisted at one operation for perforated gastric uleer in which the operator placed a drain at the site of the perforation. Leakage oceurred with a resulting gastric fistula and death of the patient from inanition. Given a reeent perforation, should the patient be placed in the Fowler position? If the peritonitis is generalized, suprapubic drainage should be established and the head of the bed elevated. If, however, the soiling is confined to the upper abclomen, the foot of the bed should be raised in order to prevent dissemination of the infection. Gastro-enterostomy is in a transition stage at present and its indications and contraindications are not fixed. It shonld rarely be performed at the time 
a perforation is closed. An alarming number of cases of peptic ulcer of the jejunum have been reported as a sequel of gastroenterostomy, a number of which have perforated. Several have been operated upon and some of these have recovered. All were foreign cases.

As to peritonitis without visceral lesion, Dr. Stewart has seen several instances in which the diagnosis was confirmed post mortem. In one case which survived, the gonococcus was found. A second case was that of a woman with a diagnosis of typhoid fever and a supposed perforation. Operation revealed peritonitis but no indication of typhoid fever and no visceral lesion. Cultures showed the pneumococcus. A third case was one of typhoid fever operated on for perforation; no perforation was found and the patient recovered. If the causative lesion be not found at once it is best to make a further careful scarch, as the lesion will almost always be finally located. Dr. Stewart assisted at one operation for supposed appendicitis in which suppurative peritonitis was found. Air came out of the abdomen but the operator simply removed the appendix, although that organ did not appear to be much discased. Autopsy showed a leaking gastric ulcer which a more careful search would have located.

Local anxstliesia is often useful for exploratory purposes, but its use in these cases should be limited to the diagnosis of peritonitis. If this condition be found, general anæsthesia should be employed, as washing out of the abdomen or searching for a perforation cannot well be performed even in the adult by the use of a local anæsthetic.

Dr. JoHn B. Ronerts cited a case of traumatic ulcer of the stomach which was mistaken for a peptic ulcer. When the abdomen was opened for repeated vomiting of bloorl there was found a thickening of the posterior wall of the stomach near the pylorus. Dr. Roberts did a posterior gastro-enterostomy which was followed by the vicious circle. Dr. Stewart operated later for this condition, and found two sewing needles, one in the liver and one behind the stomach, which Dr. Roberts had not left in the abdomen. The woman afterward gave a clear history of having eaten pie, some months previously, in which there was some foreign body which gave intense pain at the time of swallowing. Soon after this she had profuse vomiting of blood and applied to a dispensary for treatment. The swallowed needles 
were evidently the eanse of the bleeding and probably eaused a ehronic uleer where the thiekening in the stomaeh-wall was felt at the time of the first operation. The case is a warning against being in too great a hurry to nake the diagnosis of peptic uleer before getting as full a listory as is possible.

Dr. Cirarles H. Frazier alluded to a ease at the University Hospital operated on by Dr. Norris for strangulated hernia. The following morning the patient showed evidence of collapse and it was thought that a ligature had slipped, giving rise to internal hæmorrhage. An exploratory laparotomy revealed a perforated gastric ulcer and the abdomen filled with blood. The perforation was elosed bnt the patient did not react from the shoek of operation and soont clied.

Dr. Joirn B. Ronerts said lie had lost two patients from perforation of gastric uleer a considerable time after operation in the pelvis. One was a man upon whom he had performed suprapubic lithotomy; the other was a case of extraperitoneal rupture of the bladder, cloing well after ineision and drainage, in which death studdenly oeeturred. The abdomen was found at antopsy to be full of blood from sudden perforation of an ulcer of the stomael. There may be some definite eonneetion between septic processes in the pelvis (one of his eases had suppurated) and duodenal or gastric ulcer, just as in the case of similar ulcers developing after severe burns of the skin.

Dr. Lr CONTE, in elosing, made elear his position regarding drainage in cases of perforated gastric ulcer. In the majority of eases seen by the surgeon the abdomen is not opened within an an hour or two after perforation has occurred. When the extent of the soiling is as far as one ean see or feel, then the case slould be treated as one of general peritonitis, the patient placed in the exaggerated Fowler position, with suprapubie drainage and employment of the other measures advised by Murphy. If one ean use this proeedure with suceess in the presence of an extensive peritonitis, why should it clo harm where the peritoneal inflammation is more limited? This method of treatment does no harm and can do good.

As to peritonitis without viseeral lesion, the condition is not common, yet most surgeons lave seen one or more eases. In one ease seen in the Childrens Hospital, the attending pliysieian and Dr. Le Conte had a long dispute, the former believing it to be 
one of peritonitis, the latter considering it pnemmonia. After a delay of 48 hours Dr. Le Conte opernted and found a diffuse peritonitis but no visecral lesion to account for it. The pneumococcus was isolated from the peritoneal contents and the autopsy showed that the infection had passed through the diaphragm from a pneumonic lung. He nade this crror because pain is often referred to the abdomen instead of to the chest in beginning pneumonia.

Dr. MARtin, in closing, said he did not wish to be understood as advising against thorough search for a possible visceral lesion. He meant to say that in the absence of local symptoms and previous history explorntory opening may be sufficient. The Germans are the only people who ean stand abdominal operations under local anxsthesia. In answer to a question by Dr. Ross, Dr. Martin said that peritonitis in the cases reported was not due to an intussusception which had been self-reduced.

\section{STRANGULATED HERNIA OF THE OVARY IN A TWO MONTHS OLD INFANT.}

Dr. EDiYard B. Hodge reported this case, which occurred in an Italian child. There had been a small umbilical hernin following infection of the cord at birth, but otherwise the child was healthy. Two wceks before admission a lump appeared in the right groin and four days later the child became fretful. On a Saturday the child vomited but had a stool as the result of an enema. On Sunday it vomited a number of times and on Monday was sent to the hospital. It had been in shock but condition on admission was good. It apparently had a hard strangulated hernia. Operation under chloroform showed a thick hernial sac which contained a swollen and discolored ovary, alınost black, three and onc-half by one and three-fourths centimeters in size. There was no intestine in the sac. The ovary and tube were tied off and the parts repaired as well as possible. The child had good convalescence except occasional vomiting, and now appears to be well. It is a question if the condition of the ovary was not due to torsion or injury, as he is not satisfied there was constriction sufficient to cause the lesion present. To decide if there was a uterus bicornis it would have been necessary to enlarge the internal ring, and this was not considered justifiable. Hernia of 
the ovary is not cxtrcmcly rare but appears uncommon enough to warrant the report of a ease occurring at this agc.

Dr. JoHN H. Jopson belicves this patient is one of the youngest subjects of opcration for hernia of the ovary on record. A case of hernia of the utcrus and ovary operated upon in a child of seven months has bcen rcported by Defontainc. In eases of hernin of these organs therc is frequently some congenital abnormality, as bicornatc utcrus, imperforatc vagina, or pseudohermaphroditism. A casc sueh as that reportcd by Dr. Hodge might lead to hernia of the utcrus if adlhcsions of the ovary to the sac werc prescnt. In such cascs the round ligament not infrequently is short and this aids in the production of the hernia of the uterus.

Dr. Grorge Erety Shommaker said he saw the patient referred to by Dr. Hodge three days before it was operated on. The mass in the groin was at first a small, painless swelling which he thought was infiltrated omentum. He advised temporizing on aceount of the baby's age, but at the end of three days the mass was four or fivc times as large as it was before and there was vomiting and subnormal temperature. He then sent the elild to the hospital. The eondition was no doubt congcnital.

\section{LARGE CYSTIC KIDNEY.}

Dr. Join H. Gibbon showed a spceimen of cystic kidney in which the renal tissue had becn entirely obliterated, none being demonstrable by the microseope. The question of diagnosis was interesting, the easc being sent in as an ovarian eyst. In many respeets it resembled that condition, but the diagnosis of eystic kidney was confirmed when the patient was put upon the operating-tablc. The tumor cxtcuded from the pelvis to the eostal border and it would cvidently have bcen foolish to attcmpt its removal posteriorly, hence it was takcn out through the abdomcn. It was tapped bcforc removal and elcven pints and four ounces of fluid withdrawn. This was aceomplished as easily as any nephrectomy he lias ever pcrformed. The ineision was made through the shcatli of the right rcctus muscle, the muscle pulled aside and the sheath opened beneath it. Five or six inches of the ureter, which was as large as the thumb, were removed, with the kidney. The remainder of the ureter was not explored, though this should have been done. This point was not considered until the ureter had been ligated, and then, as the patient 
was old and not in good condition, it was allowed to remain. Vaginal examination before operation revealed no stone in the lower part of the ureter. As high as 60 ounces of urine a day has been secreted by the patient sinee the operation. The vessels in the pelvis of the kidney were so distinct at the time of operation there was no trouble in their ligation. The vena eava was exposed for a length of six inehes. Dr. Gibbon believes it is better in the ease of a large growth of the kidney to go in anteriorly. Opening through the peritoneal eavity does not interfere with drainage.

Dr. Ronent G. Le Conte stated that tumors of the right. kidney are easy to remove under the eireumstanees narrated by Dr. Gibbon, the eolon usually being internal to the mass. In the left kidney, however, the deseending eolon is often to the outer side and the tumor presents under the inesocolon. Consequently, the mesentery must be incised, and if the tumor is a large one the left eolic artery must be divided before the removal can be effected. Ligature of this vessel endangers the life of the descending eolon and is not infrequently followed by gangrene. 